\title{
Correlation between Heart and Liver Iron Levels and Serum Ferritin in Patients with Sickle Cell Disease "A local Experience"
}

\author{
Zizi saad $^{1 *}$ and Ragab H Donkol ${ }^{2}$ \\ ${ }^{1}$ Department of cardiology, Zagazig University, Egypt \\ ${ }^{2}$ Department of Radiology, Zagazig University, Egypt
}

Submission: March 28, 2019; Published: April 09, 2019

*Corresponding author: Zizi saad, Department of cardiology, Zagazig University, Egypt.

Ragab Hani Donkol, Department of Radiology, Zagazig University, Egypt

\begin{abstract}
Aim of the study: Is to evaluate cardiac and hepatic transfusional iron overload in a series of teenagers and young adults sicklers by using a relaxometric T2* technique. Material and Methods: The study was performed on 25 transfusion-dependent sickler patients (13 men and 12 women), with median age of 22 years. Relaxometric T2* cardiac and liver scans were performed on a 1.5 Tesla Magnetic Resonance Imaging (MRI) scanner.

Results: No patients manifested with cardiac siderosis. Cardiac T2* was not significantly correlated with Hemoglobin (Hb), Ferritin, and liver T2*. No significant correlation was found between liver $\mathrm{T} 2 *$ and $\mathrm{Hb}$; while a significant moderate negative correlation (rs -0.45 ; $\mathrm{p}$ value 0.024) was noted between liver T2* and serum Ferritin. Liver Iron Content was low/normal ( $<7 \mathrm{mg} \mathrm{Fe} / \mathrm{g} \mathrm{dw}$ ), moderately increased (7-14mg $\mathrm{Fe} / \mathrm{g} \mathrm{dw})$, and severely increased in, respectively $12(48 \%), 7(28 \%)$ and $6(24 \%)$ patients. A low serum ferritin level $(<1500 \mathrm{ng} / \mathrm{ml}) \mathrm{indicated} \mathrm{a}$ low Liver iron concentration (LIC) $(<7 \mathrm{mg} \mathrm{Fe} / \mathrm{g} \mathrm{dw})$ in $7 / 8$ (88\%). An intermediate increase $(1500-3000 \mathrm{ng} / \mathrm{ml})$, and an increased level $(>3000$ $\mathrm{ng} / \mathrm{ml}$ ) of serum ferritin indicated a significantly increased LIC (>7 mg Fe/g dw) in receptively 7/10 (70\%), and in 5/7 (71\%) of patients.
\end{abstract}

Conclusion: Our series shows that the correlation between liver iron content and serum Ferritin level is only moderate; liver $\mathrm{T} 2 *$ scan should be considered to adjust chelation especially in patients with intermediate serum Ferritin Level.

Keywords: Sickle cell disease; Iron overload; Chronic transfusions; Magnetic resonance imaging

Abbrevations: MRI: Magnetic Resonance Imaging; SCD: Sickle Cell Disease; LIC: Liver Iron Concentration; ACH: Aseer Central Hospital; FOV: Field of View; ROI: Region of Interest; Hb: Hemoglobin; Interquartile Range; TM: Thalassemia Major

\section{Introduction}

Patient with Sickle cell disease (SCD) have experienced a great amelioration in quality of life, appreciations goes to the introduction of modern transfusions of filtered red cells [1]. However, blood transfusions cause iron accumulation over the years, and in the absence of physiologic ability to excrete excess iron [2], there is a progressive damage of major organs; such as the heart, the liver, and endocrine system [3]. End organ damage results from lipid peroxidation thru formation of reactive oxygen species by non-transferring bound iron, especially the labile plasma iron subset [4]. Therefore, chelation therapy is necessary to prevent iron accumulation and/or to remove excess iron [2].

Several techniques can be used to assess iron overload. Traditionally, liver iron concentration (LIC) by liver biopsy is considered the gold standard to predict iron overload, and a value of $7 \mathrm{mg} / \mathrm{g}$ liver has been used as a guide to start chelation in both pediatric and adult patients [5,6]. LIC $<7 \mathrm{mg} / \mathrm{g}$ is not associated with obvious hepatic pathology, while $>14 \mathrm{mg} / \mathrm{g}$ is consistently associated with liver fibrosis [4]. The use of biopsy-measured LIC as a marker of iron overload is limited by the small but finite risk of complications of liver biopsy, lack of reproducibility of quantitative assays, and sampling error [4]. Noninvasive methods including blood tests (Ferritin and iron saturation) and imaging techniques (MRI-based techniques) have been evaluated as predictors of LIC. Ferritin has been shown to correlate with LIC in thalassemia major, but the correlation in SCD is less clear [4]. Iron overload in SCD differs from thalassemia major, where regular transfusions start later. Inflammation related increased synthesis of hepcidin decreases iron absorption and enhances retention of iron within the reticulo-endothelial system [1], and there is 
less pronounced extrahepatic distribution with rare cardiac iron overload or endocrinopathies [3]. However, the profile of SCD iron overload in SCD has changed in recent years; indeed, long-term transfusion therapy has significantly increased in both children, mainly because of the primary prevention of stroke, and adults, due to increased life expectancy [3]. Heavily iron overloaded SCD have comparable risk of death as those with thalassemia major, and cardiomyopathy is the cause of $30 \%$ of deaths [7].

Chelation should be closely monitored to ensure optimal treatment. Serum ferritin levels should be obtained at least quarterly to follow trends in iron loading. Liver and cardiac MRI scans generally are obtained annually. Optimally LIC should be maintained to less than 2 and cardiac T2* more than $20 \mathrm{~ms}$. In general, when the cardiac T2* decreases to less than $20 \mathrm{~ms}$, and especially less than $10 \mathrm{~ms}$, or when the LIC is higher than $7 \mathrm{mg} / \mathrm{g}$ $\mathrm{dw}$ and not improving, better chelation is needed thru increasing dose and improving adherence. The addition of a second chelator can be taken into consideration, especially if iron burden is at very concerning levels (LIC $>15 \mathrm{mg} / \mathrm{g} \mathrm{dw}$ or cardiac T2 $*<10 \mathrm{~ms}$ ) or if adverse effects prevent dose escalation [2].

The objective of this study was to examine the extent of myocardial and hepatic Iron overload (siderosis) using MRI Relaxometer T2* Technique, and to evaluate its clinical associations in chronically transfused patients with SCD.

\section{Material and Methods}

\section{Study population}

A prospective observational study was done for 25 patients including 13 men and 12 women with a median age of 22 years (range: 17 to 24). All patients were transfusion-dependent sickle cell anemia patients recruited from Hematology Department in Aseer Central Hospital (ACH), Abha, Saudi Arabia, most having required blood transfusions from early childhood. Clinical information regarding duration of transfusion, history of splenectomy, chelation therapy, hemoglobin level, liver function test, and ferritin levels were collected. Patients gave their informed consent. The study was approved by the hospital ethics committee. All patients underwent cardiac and hepatic iron overload measurements by MRI T2* scanning between June of 2017and August of 2018 in the Medical Imaging Department of ACH using the imaging protocol previously elaborated in literatures [8-13].

\section{Scanning the MRI T2* Phantom}

Site qualification and initiation requires the site to scan test object or "phantom" prior to conducting patient studies for imaging facility qualification. The phantom used and software for analysis was provided from BioMed Informatics, LLC 31225 La Baya Dr, Suite 200 Westlak Village, and CA. The precision and accuracy of T2* MRI measurements were assessed by measuring a series of $\mathrm{MnCl} 2$ solutions with different concentrations for phantom calibration. Measurements of $\mathrm{T}^{*}$ for a series of ten aqueous $\mathrm{MnCl} 2$ phantoms with a range of ionic concentrations resulting in theoretical $\mathrm{T} 2 *$ values from 1 to $24 \mathrm{~ms}$ were made in the scanners $[14,15]$.

MRI acquisition instructions for phantom scanning are found in Table 1.

Table 1: MRI T2* Phantom Technical Specifications.

\begin{tabular}{|c|c|}
\hline Parameter & Guideline Value \\
\hline Coil & Chest/torso \\
\hline Plane & Coronal Plane \\
\hline Triggering & non \\
\hline Slice Thickness & $10 \mathrm{~mm}$ \\
\hline FOV (read/phase) & $28 \mathrm{~cm} / 28 \mathrm{~cm}$ \\
\hline Flip angle & 20 degrees \\
\hline Matrix & $128 \times 128$ \\
\hline TE & $0.99-16.5$ with $1.4 \mathrm{~ms}$ increments \\
\hline TR & $200 \mathrm{~ms}$ \\
\hline Sample bandwidth & $1560 \mathrm{~Hz} / \mathrm{pixel}$ \\
\hline Flow compensation & Off \\
\hline Fat saturation & Off \\
\hline
\end{tabular}

\section{MRI protocol and analysis}

Sedation was not required for this clinical study, as all patients are adults and cooperative. Exam duration was approximately 45 to 60 minutes. Patients were examined in the supine, head first position. Phased array torso and dedicated cardiac coil were used during scanning. Cardiac gating was used to decreases cardiac motions artifacts and respiratory bellows monitoring was used assess cooperation with breath- holding.

Cardiac $\mathrm{T}^{*}$ and Liver $\mathrm{T} 2 *$ scans were performed during the same exam on the same scanner by using a dedicated cardiac coil for Cardiac MRI and phased torso coil for the liver scan. All patients were scanned on a 1.5 Tesla MRI scanner (Intera, Philips Medical Systems, Best, the Netherlands).

\section{MR Imaging Protocol}

The following scan order and naming convention is required:

1) 3-plane localizer

2) Coil reference

3) Cardiac localizers (up to 3 series)

4) Cardiac T2* (1 short axis slice)

5) Liver $\mathrm{T} 2 *$ (3 axial slices)

\section{Cardiac T2* Acquisition}

For cardiac iron evaluation, the double inversion recovery "black blood" sequence were used as it has shown greater reproducibility than the white blood" sequence; especially in patients with higher $\mathrm{T} 2 *$ values (less iron) as the blood signal is minimized. 
Using a multi-plane localizer ensured the heart is at the center of the magnetic field. Using 2 and 4 chamber and short axis scouts select a mid-ventricular imaging plane (usually mid papillary muscle level) not encroaching on the outflow tract. Table 2 summarized the parameters for cardiac T2* imaging. To calculate the $\mathrm{T} 2 *$ value of the myocardium, a region of interest was drawn in the ventricular septum, avoiding blood pool and cardiac vessels. Predicted myocardial iron concentration was converted from the T2* value according to the study of Carpenter et al. [16], Values of T2* less than $20 \mathrm{~ms}$ were regarded as abnormal cardiac iron levels.

Table 2: Parameters for cardiac T2* Imaging.

\begin{tabular}{|c|c|}
\hline Parameter & Guideline Value \\
\hline Coil & Chest/torso \\
\hline Triggering & ECG \\
\hline Slice Thickness & $10 \mathrm{~mm}$ \\
\hline FOV (read/phase) & $40 \mathrm{~cm} /$ Variable \\
\hline Flip angle & 20 degrees \\
\hline Matrix & $128 \times 256$ \\
\hline TE & $99-125$ \\
\hline TR & $200 \mathrm{~ms}$ \\
\hline Sample bandwidth & $810 \mathrm{~Hz} / \mathrm{pixel}$ \\
\hline Flow compensation & on \\
\hline Fat saturation & Off \\
\hline
\end{tabular}

\section{Liver T2* Acquisition}

Table 3: Parameters for hepatic T2* Imaging.

\begin{tabular}{|c|c|}
\hline Pulse Sequence & TFE \\
\hline Imaging Coils & Phased array torso\& body coil \\
\hline Slice Thickness & $10 \mathrm{~mm}$ \\
\hline Slice Thickness/slices per BH & 5-May \\
\hline Bandwidth & Min water-fat shift \\
\hline BlackBlood & No \\
\hline Flyback & No \\
\hline Flip angle & 20 degrees \\
\hline Repetition Time & $100 \mathrm{~ms}$ \\
\hline First Echo & Min \\
\hline Echo spacing & $0.75 \mathrm{~ms}$ \\
\hline Echos No & 16 \\
\hline Final Echo Time & $12-14 \mathrm{~ms}$ \\
\hline FOV (read/phase) & $40 \times 24-30 \mathrm{~cm}$ \\
\hline Frequency Matrix & $96-128$ \\
\hline Phase Matrix & $64-96$ \\
\hline Acquisitions (NEX on GE) & 1- Breathheld \& 3 - Free breathing \\
\hline
\end{tabular}

Imaging parameters for the liver $\mathrm{T}^{*}$ assessment are summarized in Table 3 . Liver acquisition will consist of using the torso phased array coil. The acquisition will consist of 4-5 contiguous slices, collected in a single breath hold, centered in the middle of the liver. Imaging voxels are large to improve signal to noise ratio and to decrease minimum echo time. Voxels should be 4-5 $\mathrm{mm}$ in-plane and $10 \mathrm{~mm}$ through plane (slice thickness). Field of view (FOV) should be adjusted to body habitus, but not decreased below $32 \mathrm{~cm}$ because small FOV may prolong echo' times. Repetition time and flip angle should be $100 \mathrm{~ms}$ and 20 degrees, respectively. Echo' times should be sampled between 12 and $14 \mathrm{~ms}$.

Liver $2^{*}$ was measured from 5 regions of the mid hepatic slice. Region of interest (ROI) was drawn near the periphery of the liver, excluding obvious hilar vessels or breathing artifacts. Then the median liver $\mathrm{T}^{*}$ (ms) was calculated. The liver iron content (mg $\mathrm{Fe} / \mathrm{g} \mathrm{dw}$ ), which is the predicted hepatic iron concentration, was converted from the $\mathrm{T} 2 *$ value according to validated calibrations curves using software provided by BioMed Informatics, LLC 31225 La Baya Dr, Suite 200 Westlak Village, CA [17,18].

\section{Statistical Analysis}

Statistical analysis was performed on the Vassar Stats Website for Statistical Computation (http://vassarstats.net/index.html). Quantitative data are expressed as medians with interquartile ranges, while qualitative variables are presented as frequencies and percent. Correlation between cardiac and liver $\mathrm{T} 2 *$, and their correlation with ferritin and hemoglobin ( $\mathrm{Hb}$ ) levels has been evaluated by Spearman rank correlation test; results are presented as rs ( $\mathrm{p}$ value). Association of cardiac and liver $\mathrm{T} 2 *$ with prior splenectomy and transfusion rate has been assessed by the Mann-Whitney test; results are presents as $p$ values. Two sides $p$ values $\leq 0.05$ are considered as significant.

\section{Results}

\section{Hematologic and Iron Overload Data}

Table 4 presents the baseline demographics, hematologic and iron overload results. Of the 25 patients, 13 men and 12 women, median age of 22 years (interquartile range (IQR) 17-24 years), $15(60 \%)$ were receiving regularly transfusions, 12 had a history of splenectomy (48\%), and 6 (24\%) had elevated liver enzymes, but no one had positive markers of hepatitis. All patients were receiving hydroxyurea as chelator. The median $\mathrm{Hb}(\mathrm{g} / \mathrm{dl})$ and Ferritin (ng/ml) levels were respectively 7.8 (IQR, 7.4-8.6) and 1970 (IQR, 960-2966). The median liver T2* (ms), liver iron content (mg Fe/g dw) and cardiac T2* (ms) were respectively 3.4 (IQR, 2.05-8.73), 9.7 (IQR, 4.14-15.26), and 31.4 (IQR, 28.833.4). Considering thresholds of $20 \mathrm{~ms}$ for cardiac $\mathrm{T} 2^{*}$ no patients manifested with cardiac siderosis. LIC was low/normal $(<7 \mathrm{mg}$ $\mathrm{Fe} / \mathrm{g} \mathrm{dw}$ ), moderately increased (7-14 mg Fe/g dw), and severely increased in, respectively 12 (48\%), 7 (28\%) and $6(24 \%)$ patients.

IN Table 5, Cardiac T2* was not significantly correlated with $\mathrm{Hb}$, Ferritin and liver T2* (rs respectively $0.02,-0.01$ and 0.26 ; $\mathrm{p}$ values respectively $0.921,0.984$ and 0.209 ). No significant correlation was found between liver $\mathrm{T} 2 *$ and $\mathrm{Hb}$ ( $\mathrm{rs}-0.12$; $\mathrm{p}$ value 0.595 ), while a significant negative correlation was noted between liver T2* with Ferritin ( $r s-0.45$; p value 0.024 ). 
Table 4: Patient's characteristics.

\begin{tabular}{|c|c|c|c|c|c|c|c|c|c|c|c|}
\hline Patient & $\begin{array}{c}\text { Age } \\
\text { (Years) }\end{array}$ & Sex & $\begin{array}{c}\text { Transfusion } \\
\text { Rate }\end{array}$ & Splenectomy & Hb (g/dl) & $\begin{array}{l}\text { Hepatitis } \\
\text { Markers }\end{array}$ & $\begin{array}{c}\text { Increased } \\
\text { Liver } \\
\text { Enzymes }\end{array}$ & $\begin{array}{c}\text { Ferritin } \\
\text { (ng/ } \\
\text { ml) }\end{array}$ & $\begin{array}{l}\text { Liver T2* } \\
\text { (ms) }\end{array}$ & $\begin{array}{l}\text { Liver Iron } \\
\text { Content } \\
\text { (mg Fe/g } \\
\text { dw) }\end{array}$ & $\begin{array}{c}\text { Cardiac } \\
\mathrm{T} 2 *(\mathrm{~ms})\end{array}$ \\
\hline 1 & 20 & F & $\mathrm{R}$ & $\mathrm{Y}$ & 7.9 & $\mathrm{~N}$ & Y & 4866 & 12.2 & $3.16^{*}$ & 22.1 \\
\hline 2 & 31 & M & $\mathrm{R}$ & $\mathrm{Y}$ & 7.7 & $\mathrm{~N}$ & $\mathrm{~N}$ & 604 & 11.64 & 3.28 & 33.1 \\
\hline 3 & 15 & M & $\mathrm{R}$ & $\mathrm{Y}$ & 9 & $\mathrm{~N}$ & $\mathrm{~N}$ & 1004 & 18.24 & 2.34 & 32.9 \\
\hline 4 & 13 & $\mathrm{~F}$ & $\mathrm{R}$ & $\mathrm{Y}$ & 3.8 & $\mathrm{~N}$ & $\mathrm{~N}$ & 828 & 10.56 & 3.54 & 33.4 \\
\hline 5 & 26 & M & $\mathrm{R}$ & $\mathrm{N}$ & 8.9 & $\mathrm{~N}$ & $\mathrm{~N}$ & 3591 & 3.74 & 8.72 & 30.4 \\
\hline 6 & 25 & M & $\mathrm{R}$ & $\mathrm{N}$ & 8.5 & $\mathrm{~N}$ & $\mathrm{~N}$ & 1940 & 4.58 & 7.25 & 23.4 \\
\hline 7 & 21 & M & 0 & $\mathrm{Y}$ & 8.6 & $\mathrm{~N}$ & $\mathrm{Y}$ & 807 & 5.92 & 5.77 & 41.3 \\
\hline 8 & 31 & $\mathrm{~F}$ & 0 & $\mathrm{~N}$ & 7.7 & $\mathrm{~N}$ & $\mathrm{~N}$ & 1697 & 9.71 & 3.79 & 31.4 \\
\hline 9 & 12 & M & $\mathrm{R}$ & $\mathrm{N}$ & 8.1 & $\mathrm{~N}$ & $\mathrm{~N}$ & 3393 & 3.35 & 9.66 & 38.8 \\
\hline 10 & 34 & F & 0 & $\mathrm{~N}$ & 7.9 & $\mathrm{~N}$ & $\mathrm{~N}$ & 2784 & 2.16 & 14.59 & 31.4 \\
\hline 11 & 21 & M & 0 & $\mathrm{Y}$ & 7 & $\mathrm{~N}$ & $\mathrm{Y}$ & 1802 & 2.4 & 13.2 & 31.1 \\
\hline 12 & 30 & M & 0 & $\mathrm{Y}$ & 8.8 & $\mathrm{~N}$ & $\mathrm{~N}$ & 5367 & 1.07 & 28.74 & 30.9 \\
\hline 13 & 17 & $\mathrm{~F}$ & $\mathrm{R}$ & $\mathrm{N}$ & 7.6 & $\mathrm{~N}$ & $\mathrm{~N}$ & 2550 & 2.75 & 11.61 & 24.6 \\
\hline 14 & 31 & M & $\mathrm{R}$ & $\mathrm{Y}$ & 7.4 & $\mathrm{~N}$ & $\mathrm{Y}$ & 3671 & 2.54 & 12.51 & 38.7 \\
\hline 15 & 34 & $\mathrm{~F}$ & 0 & $\mathrm{~N}$ & 8.8 & $\mathrm{~N}$ & $\mathrm{~N}$ & 2824 & 1.94 & 16.16 & 38.3 \\
\hline 16 & 18 & M & $\mathrm{R}$ & $\mathrm{Y}$ & 7.7 & $\mathrm{~N}$ & $\mathrm{~N}$ & 2784 & 2.05 & 15.26 & 28.4 \\
\hline 17 & 33 & $\mathrm{~F}$ & 0 & $\mathrm{~N}$ & 8.6 & $\mathrm{~N}$ & $\mathrm{~N}$ & 2790 & 2.24 & 14.09 & 40.9 \\
\hline 18 & 36 & $\mathrm{~F}$ & 0 & $\mathrm{~N}$ & 8.1 & $\mathrm{~N}$ & $\mathrm{~N}$ & 4652 & 1.82 & 17.18 & 28.7 \\
\hline 19 & 18 & $\mathrm{~F}$ & 0 & $\mathrm{Y}$ & 7.4 & $\mathrm{~N}$ & $\mathrm{~N}$ & 2000 & 6.69 & 5.18 & 32.8 \\
\hline 20 & 12 & M & $\mathrm{R}$ & $\mathrm{N}$ & 8.7 & $\mathrm{~N}$ & $\mathrm{~N}$ & 1821 & 16.39 & 2.53 & 26.8 \\
\hline 21 & 15 & $\mathrm{~F}$ & $\mathrm{R}$ & $\mathrm{N}$ & 5.5 & $\mathrm{~N}$ & $\mathrm{Y}$ & 255 & 10.03 & 3.69 & 28.9 \\
\hline 22 & 49 & $\mathrm{~F}$ & $\mathrm{R}$ & $\mathrm{N}$ & 8.212 & $\mathrm{~N}$ & $\mathrm{~N}$ & 4866 & 8.39 & 4.28 & 36.8 \\
\hline 23 & 26 & $M$ & $\mathrm{R}$ & $\mathrm{Y}$ & 7.2 & $\mathrm{~N}$ & $\mathrm{Y}$ & 712 & 10.2 & $3.64^{*}$ & 28.8 \\
\hline 24 & 15 & $\mathrm{~F}$ & $\mathrm{R}$ & $\mathrm{N}$ & 6.8 & $\mathrm{~N}$ & $\mathrm{~N}$ & 1115 & 8.73 & 4.14 & 33.3 \\
\hline 25 & 22 & M & 0 & $\mathrm{Y}$ & 8.5 & $\mathrm{~N}$ & $\mathrm{~N}$ & 590 & 1.22 & 25.29 & 28.8 \\
\hline
\end{tabular}

Table 5: Spearman Rank Correlation test results (*: Significant difference).

\begin{tabular}{|c|c|c|c|}
\hline & Hemoglobin & Ferritin & Liver T2* $^{*}$ \\
\hline Cardiac T2* $^{*}$ & $0.02(0.921)$ & $-0.01(0.984)$ & $0.26(0.209)$ \\
\hline Liver T2 $^{*}$ & $-0.12(0.595)$ & $-0.45\left(0.024^{\star}\right)$ & \\
\hline
\end{tabular}

\section{Association of liver / cardiac T2* with prior splenectomy} and transfusion rate

Table 6: Association of Cardiac and Liver $\mathrm{T}^{*}$ with Splenectomy and Transfusion rate.

\begin{tabular}{|c|c|c|}
\hline & Splenectomy & Transfusion Rate \\
\hline Cardiac T2 $^{*}$ & 0.936 & 0.317 \\
\hline Liver T2 $^{*}$ & 0.429 & 0.0561 \\
\hline
\end{tabular}

No significant association has been found between cardiac T2* with prior splenectomy and transfusion rate ( $\mathrm{p}$ values respectively 0.938 and 0.317$)$. Liver T2* association with prior splenectomy was not significant $(0.429)$, while the association with transfusion rate was at the limit of significance $(0.0526)$ Table 6.

\section{Reliability of Ferritin to predict LIC}

Table 7: Association between serum ferritin and LIC levels.

\begin{tabular}{|c|c|c|c|}
\hline & $\begin{array}{c}\text { Low } \\
\mathbf{1 1 5 0 0 n g / m l}\end{array}$ & $\begin{array}{c}\text { Intermediate } \\
\mathbf{1 5 0 0 - 3 0 0 0 n g / m l}\end{array}$ & $\begin{array}{c}\text { Increased } \\
\mathbf{3 0 0 0} \mathbf{3 0} / \mathbf{m l}\end{array}$ \\
\hline $\begin{array}{c}\text { Normal/Low } \\
<7 \mathrm{mg} \mathrm{Fe} / \mathrm{g} \\
\mathrm{dw}\end{array}$ & 7 & 3 & 2 \\
\hline $\begin{array}{c}\text { Significantly } \\
\text { Increased } \\
>7 \mathrm{mg} \mathrm{Fe} / \mathrm{g} \\
\mathrm{dw}\end{array}$ & 1 & 7 & 5 \\
\hline
\end{tabular}

Table 7 presents the association between serum ferritin and LIC levels. The serum ferritin and LIC categories ranges have been defined according to the data of Raghupathy \& Adamkiewicz $[4,19]$. A low serum ferritin level $(<1500 \mathrm{ng} / \mathrm{ml})$ indicated a low LIC $(<7 \mathrm{mg} \mathrm{Fe} / \mathrm{g} \mathrm{dw})$ in $7 / 8(88 \%)$. An intermediate increase $(1500-3000 \mathrm{ng} / \mathrm{ml})$ and an increased level $(>3000 \mathrm{ng} / \mathrm{ml})$ of serum ferritin indicated a significantly increased LIC ( $>7 \mathrm{mg} \mathrm{Fe} / \mathrm{g}$ $\mathrm{dw}$ ) in receptively $7 / 10(70 \%)$ and in $5 / 7$ (71\%) of patients. 


\section{Discussion}

The profile of SCD iron overload in SCD has changed in recent years; long-term transfusion therapy has significantly increased in both children, mainly because of the primary prevention of stroke, and adults, due to increased life expectancy [3]. Blood transfusions cause iron accumulation over years, and in the absence of physiologic mechanism to excrete excess iron [2]. There is a progressive damage of major organs, such as the heart, the liver and endocrine system [3]. End organ damage results from lipid peroxidation thru formation of reactive oxygen species by non-transferring bound iron, especially the labile plasma iron subset [4]. The chelation therapy goals are to reduce plasma and cytosolic levels of reactive labile iron as quickly as possible to protect tissue from iron toxicity [20].

In the current study we have used a relaxometric $\mathrm{T}_{2} *$ technique to asses liver and heart overload in a series of teenagers and young adults. In iron-loading anemias, liver iron content provides a reliable marker of total body iron to guide, monitor, and titrate therapy [21]. Relaxometric techniques have the advantage to be non-invasive in comparison to the LIC quantification by liver biopsy which considered the gold standard for this purpose. An LIC $<7 \mathrm{mg} \mathrm{Fe} / \mathrm{g} \mathrm{dw}$ is not associated with obvious hepatic pathology, while values beyond of $7 \mathrm{mg} \mathrm{Fe} / \mathrm{g} \mathrm{dw}$ liver indicates need for chelation (Raghupathy) in both pediatric and adult patients [5,6]. An LIC $>14 \mathrm{mg} \mathrm{Fe} / \mathrm{g} \mathrm{dw}$ is consistently associated with liver fibrosis [4] and the addition of a second chelator can be considered [2]. Our choice for thresholds was based on these evidences: moderate (7-14 mg Fe/g dw) and severe (>14 mg Fe/g $\mathrm{dw}$ ) hepatic iron overload were seen, respectively in $7(28 \%)$ and $6(24 \%)$ patients. Level of liver iron overload was less than the series of Aubert, including 56 liver MRI performed in 30 chronically transfused children with SCD; LIC categorization was slightly different from ours: mild or absent for LIC $<5.6 \mathrm{mg} / \mathrm{g}$, moderate: $\geq 5.6$ and $<14 \mathrm{mg} / \mathrm{g}$; severe: $\geq 14 \mathrm{mg} / \mathrm{g}$, with respective frequencies 17 (30\%), 18 SCA (32\%), and 21 (37\%). In contrast to this, the median LIC in ours series, $9.7 \mathrm{mg} \mathrm{Fe} / \mathrm{g} \mathrm{dw}$ is similar to the series of Hankins [22]: $10.3 \mathrm{mg} \mathrm{Fe} / \mathrm{g} \mathrm{dw}$ (35 patients; median age 18 years) and Badawi [23]: 8 mg Fe/g dw (32 patients; median age 15 years).

In our series, none had evidence of myocardial siderosis on cardiac MRI and all T2* values were in the normal range (>20 ms) similar to most of previous reports $[23,24]$. The largest group of SCD patients with myocardial iron overload (MIO) ever described has been reported by [25]. Of the 201 pediatric and young adult chronically transfused, six patients $(3 \%)$ have prospectively developed cardiac iron with major risk factors severe chelator noncompliance (less than 50\%) and total body iron overload (Range 22.4-53.5 mg/g dry weight). Five among these six patients had mild/moderate reduction of T2* (between 14.7 and 20ms), while only one had marked reduction $(7.8 \mathrm{~ms})$.

These findings indicate that besides total iron, other factors control iron trafficking in these organs, and iron loading and unloading occurs at different rates in different tissues [20]. In contrast, thalassemia major (TM) patients have more frequently extrahepatic iron overload especially cardiac iron overload or endocrinopathies [3].

Serum markers, such as serum iron, transferrin, and ferritin, provide the simplest and least expensive method to assess body iron stores and despite of limited correlation with quantitative LIC. They remain the primary means of diagnosis and are often used to initiate and modify chelation therapy [26]. Serum ferritin level has been shown to correlate with LIC in Thalassemia Major (TM), but the correlation in SCD is less clear [4]. Ferritin levels are increased, not only by iron overload, but are also significantly increased by interleukin 6 in responses to inflammation. In our series, a significant moderate correlation between serum ferritin and LIC was noted. Besides assessment of this correlation, we have focused on the reliability of serum ferritin to predict a significant increase of LIC ( $>7 \mathrm{mg} \mathrm{Fe} / \mathrm{g} \mathrm{dw}$ ). Serum ferritin level was categorized according to the results of stroke prevention trials STOP and STOP 2 [19]: low $(<1500 \mathrm{ng} / \mathrm{ml})$, intermediate $(1500-3000 \mathrm{ng} / \mathrm{ml})$ and increased $(>3000 \mathrm{ng} / \mathrm{ml})$. A low serum ferritin level indicated a low LIC $(<7 \mathrm{mg} \mathrm{Fe} / \mathrm{g} \mathrm{dw}$ ) in 7/8 (88\%). An intermediate increase $(1500-3000 \mathrm{ng} / \mathrm{ml})$ and an increased level ( $>3000 \mathrm{ng} / \mathrm{ml}$ ) of serum ferritin indicated a significantly increased LIC ( $>7 \mathrm{mg} \mathrm{Fe} / \mathrm{g} \mathrm{dw}$ ) in receptively 7/10 (70\%) and in $5 / 7(71 \%)$ of patients. Our results do not indicate clear difference in the predictive value for significant LIC between the intermediate and high serum ferritin levels. This is in opposite of the STOP/ STOP2 results, where a gradual increase of the serum transferring the predictive value for significant increase of LIC has been noted: $63 \%, 78 \%$ and $88 \%$ for serum ferritin levels, respectively, 1500 $2250 \mathrm{ng} / \mathrm{ml}, 2250-3000 \mathrm{ng} / \mathrm{ml}$, and $>3000 \mathrm{ng} / \mathrm{ml}$. This difference is likely related to the smaller size of our series, in comparison to the STOP/STOP2 trials where the predictive value of serum ferritin level was based on 164 observations (77 patients).

In our series, the serum ferritin level was not correlated with cardiac T2*, similarly to previous series [24,27]. In the series of Aubart [24], all 5 measurements of moderate or severe cardiac iron overload concerned patients with TM with ferritin levels systematically below $1500 \mathrm{mg} / \mathrm{L}$, arguing for systematic MRI imaging, particularly in patients with TM. Besides spot serum ferritin level, the value of serum ferritin trend for MRI tissue T2* trend (liver and cardiac) has been investigated by Aubart [24]. For the liver, similar, opposite and inconclusive (one trend is stable whereas the other shows either increase or decrease) trends were seen in, respectively, 13, 3 and 11 SCD patients. For the myocardium, similar, opposite and inconclusive trends were observed in, respectively, 2, 5 and 6 patients. This was in contrast to thalassemia major patients in whom conflicting trends were never evidenced: 6 similar and 4 inconclusive for the liver, 3 similar and 3 inconclusive for the heart. 


\section{Conclusion}

Our series shows that correlation between Liver Iron Content and serum Ferritin level is only moderate; Liver $\mathrm{T} 2 *$ scan should be considered to adjust chelation especially in patients with intermediate serum Ferritin Level. On the other hand, cardiac $\mathrm{T} 2 *$ was not significantly correlated with hemoglobin, ferritin and liver T2*.

\section{Conflict of Interest}

There is no financial contribution to the work or potential conflict of interest.

\section{References}

1. Marsella M, Borgna-Pignatti C (2014) Transfusional iron overload and iron chelation therapy in thalassemia major and sickle cell disease. Hematol Oncol Clin North Am 28(4): 703-727.

2. Ware HM, Kwiatkowski JL (2013) Evaluation and Treatment of Transfusional Iron Overload in Children. Pediatr Clin North Am 60(6): 13931406.

3. Thuret I (2013) Post-transfusional iron overload in the haemoglobinopathies. C R Biol 336(3): 164-172.

4. Raghupathy R, Manwani D, Little JA (2010) Iron Overload in Sickle Cell Disease. Adv Hematol 2010: 272940.

5. Olivieri NF (2001) Progression of iron overload in sickle cell disease. Seminars in Hematology. 38(supplement 1): 57-62.

6. Vichinsky E, Onyekwere O, Porter J, Swerdlow P, Eckman J, et al. (2007) Deferasirox in Sickle Cell Investigators, randomized comparison of deferasirox versus deferoxamine for the treatment of transfusional iron overload in sickle cell disease. Br Journal Haematol 136(3): 501-508.

7. Fung EB, Harmatz P, Milet M, Ballas SK, De Castro L, et al. (2007) Morbidity and mortality in chronically transfused subjects with thalassemia and sickle cell disease: A report from the multicenter study of iron overload. Am J Hematol 82(4): 255-265.

8. Baksi AJ, Pennell DJ (2014) T2* imaging of the heart: methods, applications, and outcomes. Top Magn Reson Imaging 23(1): 13-20.

9. Carpenter JP, He T, Kirk P, Roughton M, Anderson LJ, et al. (2011) On T2* magnetic resonance and cardiac iron. Circulation 123(14): 15191528.

10. Gandon Y, Olivié D, Guyader D, Aubé C, Oberti F, et al. (2004) Non-invasive assessment of hepatic iron stores by MRI. Lancet 363(9406): 357-362.

11. Alustiza JM, Artetxe J, Castiella A, Emparanza JI, et al. (2004) MR quantification of hepatic iron concentration. Radiology 230(2): 479-484.

12. Westwood M, Anderson LJ, Firmin DN, Gatehouse PD, Charrier CC, et al. (2003) A single breath-hold multiecho T2* cardiovascular magnetic resonance technique for diagnosis of myocardial iron overload. J Magn Reson Imaging 18(1): 33-39.

13. Pepe A, Positano V, Santarelli MF, Sorrentino F, Cracolici E, et al. (2006) Multislice multiecho T2* cardiovascular magnetic resonance for detection of the heterogeneous distribution of myocardial iron overload. J Magn Reson Imaging 23(5): 662-668.

14.Wood JC (2007) Magnetic resonance imaging measurement of iron overload. Curr Opin Hematol 14(3): 183-190.

15. St Pierre TG, Clark PR, Chua-anusorn W, Fleming AJ, Jeffrey GP, et al. (2005) Noninvasive measurement and imaging of liver iron concentrations using proton magnetic resonance. Blood 105(2): 855-861.

16. Carpenter JP, He T, Kirk P, Roughton M, Anderson LJ, et al. (2014) Calibration of myocardial T2 and T1 against iron concentration. J Cardiovasc Magn Reson 16: 62.

17. Positano V, Salani B, Pepe A, Santarelli MF, De Marchi D, et al. (2009) Improved $\mathrm{T}^{*}$ assessment in liver iron overload by magnetic resonance imaging. Magn Reson Imaging 27(2): 188-197.

18. Meloni A, Luciani A, Positano V, De Marchi D, Valeri G, et al. (2011) Single region of interest versus multislice T2* MRI approach for the quantification of hepatic iron overload. J Magn Reason Imaging 33(2): 348-355.

19. Adamkiewicz TV, Abboud MR, Paley C, Olivieri N, Kirby-Allen M, et al. (2009) Serum ferritin level changes in children with sickle cell disease on chronic blood transfusion are nonlinear and are associated with iron load and liver injury. Blood 114(21): 4632-4638.

20. Coates TD, Wood JC. (2017) How we manage iron overload in sickle cell patients. Br J Haematol 177(5): 703-716.

21. Sirlin CB, Reeder SB (2010) Magnetic resonance maging quantification of liver iron. Magn Reson Imaging Clin N Am 18(3): 359-381.

22. Hankins JS, Smeltzer MP, McCarville MB, Aygun B, Hillenbrand CM, et al. (2010) Patterns of liver iron accumulation in patients with sickle cell disease and thalassemia with iron overload. Eur J Haematol 85(1): 51-57.

23. Badawy SM, Liem RI, Rigsby CK, Labotka RJ, DeFreitas RA, et al. (2016) Assessing cardiac and liver iron overload in chronically transfused patients with sickle cell disease. Br J Haematol 175(4): 705-713.

24. Aubart ML, Ou P, Elie C, Canniffe C, Kutty S, et al. (2016) Longitudinal MRI and Ferritin Monitoring of Iron Overload in Chronically Transfused and Chelated Children With Sickle Cell Anemia and Thalassemia Major. J Pediatr Hematol Oncol 38(7): 497-502.

25. Meloni A, Puliyel M, Pepe A, Berdoukas V, Coates TD, et al. (2014) Cardiac iron overload in sickle-cell disease. Am J Hematol 89(7): 678-683.

26. Hernando D, Levin YS, Sirlin CB, Reeder SB (2014) Quantification of Liver Iron with MRI: State of the Art and Remaining Challenges. J Magn Reson Imaging 40(5): 1003-1021.

27. Anderson LJ, Holden S, Davis B, Prescott E, Charrier CC, et al. (2001) Cardiovascular T2-star (T2*) magnetic resonance for the early diagnosis of myocardial iron overload. Eur Heart J 22(23): 2171-2179. 

(C) This work is licensed under Creative

Commons Attribution 4.0 License
DOI: 10.19080/JOCCT.2019.13.555867

\begin{tabular}{|l|}
\hline \multicolumn{1}{|c|}{ Your next submission with Juniper Publishers } \\
will reach you the below assets \\
- Quality Editorial service \\
- Swift Peer Review \\
- Reprints availability \\
- E-prints Service \\
- Manuscript Podcast for convenient understanding \\
- Global attainment for your research \\
- Manuscript accessibility in different formats \\
( Pdf, E-pub, Full Text, Audio) \\
- Unceasing customer service \\
Track the below URL for one-step submission \\
https://juniperpublishers.com/online-submission.php \\
\hline
\end{tabular}

